\title{
The Study of some Eggplant (Solanum melongena L.) Genotypes under the Thermal and Hydric Stress
}

\author{
Elena CHIRA, Mihai TUDOR, Gicuța SBÎRCIOG, Maria DUMITRU \\ Research and Development Institute for Vegetable and Flower Growing Vidra \\ ${ }^{*}$ Corresponding author, e-mail: ena_chira@yahoo.com \\ Bulletin UASVM Horticulture 72(1) / 2015 \\ Print ISSN 1843-5254, Electronic ISSN 1843-5394 \\ Doi:10.15835/buasvmcn-hort:10827
}

\begin{abstract}
The weather changes over the last years determined the orientation of the research programmes towards selecting some genotypes that are resistant/tolerant to the thermic and hydric stress. Between the years 2012 and 2013, at the RDIVFG Vidra, five eggplant genotypes for testing purposes under thermic and hydric stress conditions were studied. In this regard three graduations were established for the quantity of water provided by irrigation of plants: V1-irrigated as necessary for plant growth and development, V2-irrigated in $50 \%$ of the critical moments, V3-not irrigated even from the foundation of the experiment. The plants' growth and development was influenced by the environment conditions and the technological variant, for all genotypes.
\end{abstract}

Keywords: eggplants, thermic stress, hydric stress.

\section{INTRODUCTION}

Eggplants are plants of the tropics, the warm and humid climate. The root system is well developed, but superficial. Insufficient soil water causes falling of flower buttons, flowers and even formed fruit. The water quantity consumed by the vegetable plants during the vegetation period is determined by the level of the perspiration coefficient, by the perspiration productivity, by the water balance and by the consumed water utilization coefficient (Voican et al., 1994). The selection of genotypes which are tolerant to the thermic and hydric stress represents a major objective of the eggplant breeding activity (Saleh and Saud,1995).

\section{AIMS AND OBJECTIVES}

Researches are aimed at testing the resistance/tolerance of five eggplant genotypes to thermic and hydric stress at the RDIVFG Vidra.

\section{MATERIALS AND METHODS}

Between the years 2012 and 2013, at the RDIVFG Vidra were studied five eggplant genotypes (Andra $\mathrm{F}_{1}$, Belona, Daniela, Luiza, Rodica) testing purposes under thermic and hydric stress conditions. In this regard three graduations were established for the quantity of water provided by irrigation of plants: V1-irrigated as necessary for plant growth and development, V2-irrigated in 50\% of the critical moments, V3-not irrigated even from the foundation of the experiment. Water administration to the plants was done by dripping. The significance of differences was determined by the multiple comparison method (Ceapoiu, 1968).

\section{RESULTS AND DISCUSSION}

The climate conditions of 2012 during the period of June-September (very high temperatures and both pedological and atmospheric severe drought) significantly influenced the plants' growth and development. In the technological variant $\mathrm{V} 3$, where the plants were not irrigated, the lack of water and high temperatures above $35^{\circ} \mathrm{C}$ determined great losses of plants. A percentage of plants, between 16\% (Luiza) and 54\% (Andra F1), actually developed and fruited. The duration of the plants' phenophases was also influenced by 
Tab. 1. The yielding capacity depending on technological variant

\begin{tabular}{ccccccc}
\hline Genotyp/ & \multicolumn{3}{c}{ Yield (t/ha) -2012 } & \multicolumn{3}{c}{ Yield (t/ha) -2013} \\
\cline { 2 - 7 } technological variant & $\mathrm{V} 1$ & $\mathrm{~V} 2$ & $\mathrm{~V} 3$ & $\mathrm{~V} 1$ & $\mathrm{~V} 2$ & $\mathrm{~V} 3$ \\
\hline Andra F1 & $41.4 \mathrm{a}$ & $25.6 \mathrm{~b}$ & $4.7 \mathrm{c}$ & $46.4 \mathrm{a}$ & $39.6 \mathrm{~b}$ & $28.8 \mathrm{c}$ \\
\hline Luiza & $38.6 \mathrm{a}$ & $22.8 \mathrm{~b}$ & $2.6 \mathrm{c}$ & $42.3 \mathrm{a}$ & $36.0 \mathrm{~b}$ & $27.6 \mathrm{c}$ \\
\hline Belona & $36.9 \mathrm{a}$ & $22.5 \mathrm{~b}$ & $4.2 \mathrm{c}$ & $40.6 \mathrm{a}$ & $35.3 \mathrm{~b}$ & $20.0 \mathrm{c}$ \\
\hline Rodica & $34.4 \mathrm{a}$ & $20.1 \mathrm{~b}$ & $2.3 \mathrm{c}$ & $36.3 \mathrm{a}$ & $26.8 \mathrm{~b}$ & $11.3 \mathrm{c}$ \\
\hline Daniela & $33.8 \mathrm{a}$ & $17.6 \mathrm{~b}$ & $2.2 \mathrm{c}$ & $35.8 \mathrm{a}$ & $27.2 \mathrm{~b}$ & $13.4 \mathrm{c}$ \\
\hline
\end{tabular}

the technological variant and climate conditions. In variant $\mathrm{V} 1$, the period from emergence to flowering was of 94 days for Rodica and Daniela and of 95 days for Andra F1, Luiza and Belona. In variant $\mathrm{V} 2$ the period varied between 99 days (Andra F1) and 104 days (Belona). In variant V3, this period was longer than in V1 and V2 variants, respectively 113 days for Andra F1 and 116 days for Luiza. The period from flowering to the fruits' technical maturation in V1 variant was between 31 and 34 days while in V2 variant was between 36 and 46 days. In V3 variant this period was shorter than in V1 and V2 variants, of only 23-25 days respectively. This is explained by the fact that cluster fruits were fewer and very small, as compared to the specific size of the genotype. The fruits rapidly passed to the physiological maturation phenophase and were of poor quality. The yielding capacity was determined by the number of plants per unit area, by the number of fruits per plant and by their size. Even in the technological variant V1, the high temperatures and atmospheric drought diminished the yield obtained in all cultivars, as compared to their genetic potential ( Table 1). Thus, in variant V1 the yield varied between $33.8 \mathrm{t} / \mathrm{ha}$ (Daniela) and 41.4 t/ha (Andra F1).The difference between variant V1 and variant V2 was significant, for all genotypes, the yield being between $17.6 \mathrm{t} / \mathrm{ha}$ for Daniela and $25.6 \mathrm{t} / \mathrm{ha}$ for Andra F1. In variant V3 the yield was very low, respectively $4.7 \mathrm{t} / \mathrm{ha}$ for Andra F1 and $2.2 \mathrm{t} / \mathrm{ha}$ for Daniela, being determined by the small number of surviving plants and cluster fruits, as well as by their reduced size.

The climate conditions of 2013, less stressing for the plants, and also the technological variants, did not influence the number of plants per unit area. This remained the same from the planting phase to the physiological maturation, for all genotypes. The duration of the plants' phenophases was not significantly influenced by the technological variant. The technological variants, as well as the water quantity for the plants, influenced their growth and development, the number of fruits per plant and their weight, for all genotypes. The fruits' weight in variant V1 was between $180 \mathrm{~g}$ (Rodica) and $452 \mathrm{~g}$ (Daniela). The type Daniela had very big and few fruits per plant, which made it less productive, as compared to other genotypes. In variant V3 the fruits' weight was between 103 g (Rodica) and 174 g (Daniela). The yielding capacity was also influenced by the technological variants, the obtained differences being significant for all genotypes (Table 1).

\section{CONCLUSION}

The extreme weather conditions of 2012 created the frame for genotypes' testing towards the thermal and hydric stress. The plants' growth and development was influenced by the environment conditions and the sowing time as well as by the technological variant. The percentage of plants that survived during of the main phenophases, the weight of fruits and the yielding capacity were influenced by these factors (thermic stress and hydric stress).

\section{REFERENCES}

1. Ceapoiu N. (1968). Metode statistice aplicate în experiențele agricole şi biologice. Editura Agro-Silvică, Bu curești.

2. Maria Dumitru, Elena Chira ,Gabriela Șovărel (2012) Researches on the Behaviour of Certain Genotypes of Vegetable Marrow (Cucurbita pepo L. convargiromontia Alef.) at the Thermic and Hydric Stres. Buletin of Universiyt of Agricultural Sciences and Veterinary Medicine ClujNapoca, 386-387.

3. Saleh Byari and Saud M S (1995). Morphological and Physiological Responses of Eggplant Cultivars (Solanum melongena L.) to Drought. Meteorology,Environment and Arid Land Agriculture Siences, 6: 41-46.

4. Voican V, Scurtu I, Mirghiș R, Buzescu D (1994). Particularitățile stării de secetă și consecințele acestora pentru cultura legumelor. Analele ICDLF vol. XIII., 411 424. 